\title{
Yeni Medyada Alternatif Ekonomik Model Arayışları ve Yavaş Gazetecilik: L'ora Del Pellice Üzerine Vaka Çalışması
}

Kenan Duman, İstanbul Arel Üniversitesi, Görsel İletişim Tasarımı Bölümü, Dr. Öğr. Üyesi, kenanduman@arel.edu.tr, ORCID: 0000-0001-5338-9150

$\ddot{O Z Z}$

Bu makalenin amacı "Yavaş Gazetecilik" kavramını tanımlamak, yavaş gazeteciliğin temel özelliklerini ve uygulamalarını ortaya koymaktır. Çalışmanın ana sorusu şudur: Alternatif yavaş gazetecilik pratikleri, gazeteciliğin geleceği için ne önerebilir? Çalışma soruları dört ana başlıkta toplanmıştır: Yavaş gazetecilik, hızlı gazeteciliğg bir alternatif midir? Haber tüketicisinin derinlemesine araştırılmış, şeffaf, çok kaynaklı bir haberciliğe talebi var mıdır? Yavaş gazetecilik, giderek güvenilmez hale gelen gazetecilik mesleğine güveni artırabilir mi? Yavaş gazetecilik ekonomik bakımdan sürdürülebilir mi? Çalışmada fenomen ve öncülleri bağlamsallaştırıldiktan sonra yavaş gazeteciliğin pratikte neye benzediğini görmek için İtalya'da 'Lora Dell Pelice' medya kuruluşu bă̆lamında görüşme biçimi ile araştırılma gerçekleştirilmiştir. Örnek vakada, derginin editörü ile yapılan görüşmenin yanı sıra derginin yazılı ve çevrimiçi içerikleri incelenmiştir. Çalışmanın sonucunda çŏ̆u yavaş gazetecilik projesinin okur odakl olduğunu ve kendi kitlelerini yarattıkları, ilk dönem yavaş gazetecilik deneyimlerinin kendilerini hızl gazeteciliğin yerine ya da gazeteciliğin geleceği olarak düşünmedikleri sonucuna varılmıştır. Ayrıca çalışma sonucunda yavaş gazeteciliğin hızlı haber sarmalında güvenli bir medya ortamı için bir alternatif olduğu ve ilk dönem örneklerin kısa sürede ekonomik sürdürülebilir yapı oluştursalar da ilerisi için endişeler taşıdıkları gözlemlenmiştir.

Anahtar : : Yeni Medya, Yeni Medya Ekonomisi, Yavaş Medya, Yavaş Gazetecilik

Kelimeler

\section{Search for Alternative Economic Models in New Media and Slow Journalism: A Case Study on L'ora Del Pellice}

ABSTRACT
The purpose of this article is to define "Slow Journalism" concept and reveal its basic features and applications. The main question of the study is what can the alternative slow journalistic practices suggest for the future of the journalism? Study questions are grouped under four main topics. Is Slow Journalism an alternative to Fast Journalism? Does news consumer demand for in-depth research, transparent, multisource reporting? Can slow journalism increase the confidence in journalism which is increasingly becoming unreliable? Is slow journalism economically sustainable? 
In the study, after the contextualization of the phenomenon and its predecessors, to see what slow journalism looks like in practice, a research was conducted in Italy, in the context of "Lora Dell Pelice" Media Corporate with the interview as a method. In the case study, the written and online content were examined as well as interviewing with the editor of the journal. As a result of the study, it was concluded that most of the slow journalistic projects are reader-oriented and that they create their own masses, and that the first period of slow journalism did not consider themselves to be the future of fast journalism or the future of journalism. At the end of the study, it was observed that slow journalism is an alternate for a safe media environment in the fast news spiral, and that the early examples have concerns about future even if they form a sustainable economic structure in short time.

\section{Keywords : $\quad$ New Media, New Media Economy, Slow Media, Slow Journalism \\ Gíriş}

Dijital odaklı yeni enformasyon teknolojileri, yirminci yüzyılın son çeyreğinde kısa sürede hızla yayıldı. Analog veri iletiminden dijital iletime geçiş olarak betimlenen bu dönem, enformasyon ve iletişim sinyallerinin üretimini, yayılmasını ve tüketimini büyük ölçüde arttırırken yeni dönemin anahtar kelimesi 'hız' olmuştur (Dijk, 2016: 297). Bu dönemde ortaya çıkan teknolojik gelişmelerin yansımalarını en etkili biçimde hisseden mesleklerden biri de gazetecilik olmuştur. Özellikle son yirmi yıl içinde yazılı basının büyük bir okuyucu kaybı yaşaması ve ikame medya alanı olarak şekillenen internet gazeteciliğinin organizasyonel ve ekonomik anlamda gerekli ivmeyi yakalayamaması bu çıkarımın sebepleri arasında gösterilebilir. Bu yeni dönemde gazeteciler, diğer teknolojik sosyal araçların haber ve bilgi dağıtma alanına girmesi ile haber üretim ve dağıtım aşamasındaki tekelini kaybetmeye başlamıştır. Sosyal medya ağları, bloglar vb. uygulamalar ile haber miktarında bolluk yaşanırken haber değeri gittikçe azalmış ve buna paralel olarak habere olan ilgi azalmaya başlamıştır. Yeni teknolojiler, hızlı haber konusunda profesyonel haber kuruluşlarının tekeline son verirken, "gerçek zamanlı" ücretsiz haber kaynakları önemli oranda artmıştır.

Odağında teknoloji yer alan ve önemli ekonomik sonuçlar ortaya çıkaran gelişmeler, gazetecilik mesleği için önemli zorluklar ortaya koymaya başlamıştır (Siapera ve Veglis, 2012: 3). İlk dönem çevrimiçi gazetecilik uygulamalarında haberin hızı, gazeteye göre daha fazla artarken en yeni olma kaygısı, ilerleyen dönemde içeriğe olan güvenin azalmasına neden olmuştur. Geleneksel gazetecilik alanında haber oluşturulurken yüksek kalitede araştırmaya dayalı derin hikâye anlatımı önemli bir iş yöntemi olarak görülürdü. Son yirmi yıl içinde ise artan rekabet şartları karşısında şirket maliyetlerinde tasarrufta bulunmak, hızlı ve hazır haber vermek gibi bir yönelim tercih edilmiştir. Haber merkezlerinin organizasyonel anlamda küçüldüğü yeni dönemde ajanslardan gelen bülten haberlerinin hiç müdahale edilmeden haber sitelerinde yer alması, gazeteciliğin değer yitiminde önemli bir neden olarak gösterilebilir. Özgün araştırma yerine, basın bültenleri veya ajans haberleri gibi kaynaklardan 
alınan materyallerin tekrar kullanılmasına dayanan bir türdeki gazeteciliği İngiliz gazeteci Nick Davies (2008) “Churnalism” olarak tanımlanmıştır.

Gazetecilik mesleğinde hız kavramı önemli bir bileşendir. İnsanlar olaylar hakkında mümkün olduğunca çabuk bilgi almak isterler. Haberi önce almak, önemli bir rekabet unsuru olarak mesleğin içinde yer alır. Telgraf, radyo, televizyon vb. teknolojik gelişmeler haber akışının daha da hızlandırılmasını sağlamak için önemli bir gelişme olarak karşımıza çıkmıştır. Fakat ağ sonrası dönemde, hızın bu kadar ön plana çıkması daha derinlemesine, araştırmacı haberlerin geri plana itilmesine neden olmuştur. İnternetin ortaya çıkmasıyla birlikte haberde hızlılığa yapılan vurgu, gazetecilik uygulamasında daha da artmıştır. Bu durum, geleneksel haber döngüsünü yedi gün yirmi dört saat haber üretim sürecine doğru evirtmiştir. Bu süreçle birlikte, hız konusunda devam eden stres; zaman baskısı, dikkatlilik ve hassasiyet açısından gazetecilik standartlarını aşındırmaya başlayan dezavantajlar ortaya çıkarmıştır (Drok, Hermans: 2015). Ayrıca, hızlı hazırlanan ve dağıtılan haberlerin içeriklerinin güvenilir olup olmadıkları temel bir sorun olarak karşımıza çıkmaktadır (Değirmencioğlu, 2016: 601).

Haber web sayfalarının ajanslar tarafından hazırlanan bülten haberleri ile dolduğu bu yeni dönemin ekonomik anlamda karşılığı ise, medya kuruluşlarının yerinde saydığı hatta gerilediği bir dönemdir. Ekonomik anlamda girdaptan çıkmak isteyen bazı alternatif medya kuruluşları, çözümü haber sayfalarında anlatı biçiminde uzun haber yazılarına yer vermekte bulmuştur. Mevcut gazetecilik kurumları da haber hikâyelerini yeni yollarla anlatmak için multimedya öğeleri kullanarak bu hikayeleri dijital alana aktarmaya başlamışlardır. "Yavaş Gazetecilik" olarak adlandırılan bu yeni habercilik türüne dair az miktarda bilimsel çalışma yapılmıştır. Bu makalenin amacı, "Yavaş Gazetecilik" kavramını tanımlamak ve en azından yavaş gazeteciliğin temel özelliklerini ve uygulamalarını ortaya koymaktır. Çalışmada ayrıca, yavaş gazeteciliğin pratikte neye benzediğini görmek için İtalya'da 'Lora Dell Pelice' medya kuruluşu bağlamında gözlem ve görüşme biçimi ile araştırma gerçekleştirilmiştir.

\section{Yavaş Hareketi ve Yavaş Medya Kavramı}

Kundera, (2018) 'Yavaşlık' adlı eserinde hızı, teknik devrimin insana armağan ettiği bir esrime biçimi olarak tanımlar. Kundera'ya göre insan, hız yeteneğini makineye devrettikten sonra kendisini cisimsiz, maddesiz bir hıza teslim etmiştir. Küresel çağda hıza karşı bir başkaldırı hareketi olarak ortaya çıkan Yavaş hareketinin öncül çalışmaları 1980'li yılların başında İtalya'da görülmüştür. İtalya'nın Piedmonte bölgesinde yer alan Bra şehrinde organize olan Libera e Benemerita Associazione Amici del Barolo topluluğu ve ardından ortaya çıkan İtalyan Kültürünü Canlandırma Derneği (Associazione Ricreativa Culturale Italiana/ARCI) hareketi bu hareket için ilk organizasyonlardır (Petrini, Padovani, 2012: 19). Yavaş Hareketi tam olarak, yemek yazarı Carlo Petrini'nin 1986 yılında Roma'da 'Yavaş Yemek' (Slow Food) hareketini dünyayı saran fast food kültürüne karşı kurmasıyla başlamıştır (Ritzer, 2011: 197). Yavaş 
Yemek Hareketi, yerel toplulukların ürün ve kültürünü korumak ve teşvik etmekle ilgilenirken temel isyan nedeni, uluslararası restoran zincirlerinin açıldıkları yerlerde yerel yemek ritüel ve kültürünü ortadan kaldırmalarıdır (Bulunmaz, Çetin, 2018: 96). Bu düşünceye göre, hızlı yemek yeme kültürü yerel sofra düzenini yok etmekteydi. Güven (2011: 116), Yavaş Hareketi'nin farklı alanlarda yavaşlığa dair reçeteler hazırlayarak, bireyleri küreselleşmenin yıpratıcı etkisinden kurtarmanın yollarını aradığını belirtir. Petrini (2001: 8), Yavaş Hareketi'nin sadece fast-food'a değil, aynı zamanda “yeni başlayan küreselleşmenin semptomlarına" karşı bir tepki olduğunu vurgular. Yavaşlamanın sağladığı hazlar 'Yavaş Yemek Hareketi' için önemlidir. Hareketin vurgu yaptığı nokta, küresel dünyanın oluşturmaya çalıştığı hızlı hayat kültürüne karşı kaliteli bir hayatın oluşturulması ve devam ettirilmesi gerekliliğidir (Bulunmaz, Çetin, 2018: 96). Hareketin temel anlayışı insanlığı hızlı yaşamın evrensel çılgınlığına ve maddi zevklere karşı savunmak diye özetlenirken sloganı “İyi, temiz ve adil” olmuştur (Le Masurier, 2015: 140). Hareketin temel anlatısı ise, bulunulan bilgi ve teknoloji çağında birey üzerinden toplumsal bir hız kaygısına, kaliteden uzaklaşılmasına, ekonomik güce, iktidar olanaklarına ve baskın bir homojen kültür anlayışının her şeye egemen olmasına karşı bir başkaldırıdır (Bulunmaz, Çetin, 2018: 97).

Küresel çağda hızlı üretim ve tüketim süreçleri Yavaş Medya Hareketi'nin de çıkış noktası olmuştur. Yavaş Medya hareketi, dijital teknoloji çağında yüksek medya üretim ve tüketimine karşı çıkan bir medya tüketim hareketi olmuştur. 2010 yılından başlayarak küresel olarak dünyada çeşitli ülkelerde yerel düzeyde yavaş medya örnekleri oluşmaya başlamıştır (Güven 2011: 117). Yavaş Medya Hareketi, medya üretiminin kapsamlı bir şekilde araştırılmış ve yaygın olarak erişilebilir olan medyalardan oluşması gerektiğini savunmaktadır. Okur, dijital kültür sonrası dönemde her dakika önünde olan çok sayıda bilgi ile karşı karşıyadır. Yavaş medya, karmaşık medya biçimlerine ve karakteristik özellikleri nedeniyle anlık iletişim yöntemlerine yanıt olarak geliştirilen bir yöntemdir. Yavaş medya hareketinin kendine ait bir manifestosu mevcuttur. Almanya'da Benedict Köhler, Sabria David ve Jörg Blumtritt'in oluşturduğu manifesto biçimindeki maddeler şu biçimdedir: (http://en.slowmedia.net/manifesto).

- Yavaş Medya, sürdürülebilirliğe bir katkıdır.

- Yavaş Medya, tek bir işe odaklanmayı destekler.

- Yavaş Medya, mükemmeli hedeflemektedir.

- Yavaş Medya, kalitesini hissedilir hale getirir.

- Yavaş Medya, üreten tüketiciliği geliştirir.

- Yavaş Medya, söylemsel ve diyalojiktir.

- Yavaş Medya, sosyal medyadır.

- Yavaş Medya, kullanıcılarına saygılıdır. 
- Yavaş Medya, reklamcılıkla değil, önerilerle dağıtılır.

- Yavaş Medya, zamansızdır.

- Yavaş Medya, auratiktir.

- Yavaş Medya, aşamalıdır.

- Yavaş Medya, medya içeriğinin üretiminde ve alınmasında kalite odaklıdır.

- Yavaş Medya, güven istemekte ve zamanını inandırıcı olmak için harcamaktadır (http://en.slow-media.net/manifesto).

\section{Yavaş Gazetecilik Kavramı}

Medyanın büyük oranda hazırlıksız olduğu dijital çă̆, gazeteciliğin tüm alanını etkilemiştir. Gazetecilik endüstrisinin hızla daralan ekonomisi, geleneksel yayıncıların karşısında yıkıcı rakipler, sosyal medyanın getirdiği yeni tüketim kalıpları ve viral içerik gibi faktörler alanın büyük sorunlar yaşamasına neden olmuştur. Bu gelişmeler, basın alanı için birçok zorluğu beraberinde getirirken zaman ve maddi yük gerektiren raporlama türü uzun soluklu haberler bu değişimin ilk kurbanı olmuştur. 24 saatlik haber döngüsünün içinde bir haber üretmek için genellikle aylarca çalışma gerektiren uzun biçimli gazetecilik, meslekte ilk terk edilen davranış biçimi olmuştur (Gorbachev, 2016).

Çalışmamızın konusu olan yavaş gazetecilik, habercilik davranışı olarak genellikle, olay gerçekleşirken her saat başı hızla değişen güncellemeler yapmak yerine haber hikâyesi bittikten sonra olanları ayrıntılı bir şekilde anlatmayı hedeflemektedir. Yavaş gazetecilik, hikâyenin tamamını anlatmaya odaklanan bir yaklaşımdır. Sahada çalışan gazeteciler, genellikle, bilgiyi her an toplamak için bir hikâye araştırarak aylar ya da on yıllar süren bir zaman harcamaktadır. Nihai ürün, hikâyenin yanı sıra olaydan etkilenen insanlara ve topluluklara da ulaşılmasıyla en üst düzeyde kapsamlı ve bilgilendirici biçimde ortaya çıkmaktadır. Geleneksel medya karşısında bir alt kültür hareketi olan yavaş gazetecilik, "yavaş" hareketinin devamı olarak diğer "yavaş" hareket alt grupları gibi iyi, temiz ve adil bir ürün üretme çabası değerlerini paylaşır (Le Masurier, 2015: 140). Geleneksel gazetecilikte haber sunulurken genellikle, olay ve olaya karışan insanlar ile ilgili yüzeysel bir bilgi verilirken haberden habere, hikâyeden hikâyeye kısa kısa geçilir. Yavaş gazetecilik ise, habere doğru bir son vererek hikâyeyi bitirmeyi amaçlar. Yavaş gazetecilik için sahada haber yapan gazeteciler kendilerini habere adayarak, gerçeği ortaya çıkarmak ve halkı bilgilendirmek için gereken kadar zaman harcamak amacındadır. Yavaş gazetecilikte haber hazırlama süreci, araştırmacı gazetecilikteki gibi derin bir araştırma disiplinine sahiptir. Haber hazırlanırken hız yerine zamana, haber kaynağına ulaşma koşullarına ve okur ile izleyiciye duyulan saygıya bağlı kalınır (Bulunmaz Çetin, 2018: 141). 
Yavaş Gazetecilik alanında çalışmaların başlangıcı olarak 2008 sonrası dönem görülmektedir. Yavaş Gazetecilik Kavramının tanımsal olarak oluşmasında Harcup, Greenberg ve Le Masurier önemli katkıda bulunmuşlardır. Yavaş gazetecilik terimi ilk kez Şubat 2007'de İngiliz Siyaset ve Kültür dergisi Prospect'te yayınlanan bir makalede Susan Greenberg tarafından kullanılmıştır. Greenberg, internet sonrası dönemde gazeteciliğin giderek zaman bağlamında "lüks" bir ürün haline geldiğini iddia etmiştir. Yazar, buradaki lüks kavramını, "Bir şeyleri keşfetmenin zaman alması, işleri anlamanın zaman alması, yeni bir şeyler yapmanın zaman alması ve bunu adaletli bir şekilde ifade etmenin zaman alabilmesi" olarak vurgulamaktadır. Greenberg (2017: 15), bu kavramı oluştururken bağlamsal alt yapıyı yukarıda da söz ettiğimiz "Yavaş Yemek" hareketinden almıştır. Greenberg, geleneksel gazeteciliğin okur kaybına vurgu yapar ve masa başından kalkarak ayrıntılı haber hazırlamanın lüks olduğunu vurgular. Yazar, haber hikâyelerini en yüksek standartlara ulaştıran haber ve röportaj yazıları için büyüyen bir pazarın gerekliliğine dikkat çeker: Ona göre bu kavram 'Yavaş gazetecilik' tir. Zaman ve kalitenin bu yeni tür gazetecilik için ana unsur olduğunu vurgulayan Greenberg (2007), Yavaş Gazetecilik Nedir? Sorusuna “Bir şeyler bulmak, zaman zaman başkalarının kaçırdığı hikâyeleri fark etmek ve bunların hepsini en yüksek standartlara ulaştırmak için kurgulamak" yanıtını verir. Harcup (2014), yavaş gazeteciliği kalite, derinlik ve doğruluğu hızın üstünde tutan bir gazetecilik kavramı olarak betimlemektedir. Yavaş gazetecilik savunucuları, 'yavaş gıda' hareketinden esinlenerek, gazetecilerin ofislerinin dişında olay yerinde inceleme yaparak, belge soruşturarak işlerini olması gerektiği gibi yapmak için zamana ihtiyaç duyduklarını iddia etmektedirler.

Le Masurier (2014), yavaş gazeteciliği orijinal bir konu hakkında daha derin düşünmek ve / veya o konuyu soruşturmak için zaman harcama faaliyeti olarak genelleştirmiştir. Le Masurier (2014), bu eylemin haber yazım biçiminde bir uzunluk değil, genellikle zaman biçiminde bir uzunluk olduğunun altını çizer. Ona göre, yavaş gazetecilik sansasyonalizmden kaçınır. Yavaş yaklaşım, gazeteciliğin sadece gerçek anlamda doğru olması gerektiğine değil, mümkün olduğunda kaynakların şeffaf bir biçimde doğrulanabilir ve izlenebilir olması gerektiğine vurgu yapar. Yavaş gazetecilik uygulamaları çoğunlukla küçük ölçekli, bağımsız veya alternatif bir alanda üretimden oluşmaktadır. Le Masurier (2014), yavaş gazetecilik yapan gazetecilerin haber hazırlama süresinin aylar ya da yıllar ile ölçüldüğünü, bu haber biçiminin sadece uzun yazı biçimindeki haber olarak algılanmaması gerektiğini vurgular. Yavaş gazetecilik, adını aldığı "yavaş gıda" hareketi gibi, açıklık ve şeffaflığı vurgular; izleyicilere kaynak ve yöntemleri açıklar ve nihai ürüne katılımı çağırır. Le Masurier (2015: 138-152), aşırı ve hızlı bilgi çağında gerçek zamanlı olarak bilgi üretme çabasının haberlerin doğruluğunun kaybolmasına ve doğrulama eksikliğine neden olacağını vurgular.

Yavaş gazetecilik, özellikle haberi oluşturma biçimi bakımından diğer türlerden ayrılmaktadır. Bu habercilik türünde gazetecilerin, gerçeği açığa çıkararak kamuoyuna sunmaları için yıllarını harcadıkları görülmektedir. Gerard (2009, akt. Bilecen ve Bayraktutan: 2018, 348), yavaş gazeteciliğin ayırt edici özelliklerini; rekabette yenmek üzerine 
odaklanmamış; sadece hızlı ve ilk olmaya çalışmayıp doğruluk, kalite ve bağlam değerlerine sahip; şöhret ve sansasyondan uzak; bağlamı keşfetmenin zaman aldığı; anlatılmamış hikâyeler arayan; anlatı gücüne dayanan ve okuyucuyu ortak olarak gören gazetecilik diye özetlemiştir. Bu anlamda yavaş gazetecilik, bir konu hakkında daha derin düşünme ve araştırma için zaman gerektirdiği noktasında genellenebilir. Gerard'a ek olarak yavaş gazeteciliğin; kaynakların doğrulanması ve gerçeklerin doğru bir şekilde hesaplanması için çalışan, yayınlanacak malzemenin doğru seçildiği, son dakika gündeminden bağımsız ve ele alınan konulara önyargısız yaklaşan bir gazetecilik türü olduğunu da söyleyebiliriz. Ayrıca, yeni anlatı tekniklerinin uygulanması ve sadece reklama bağlı olamayan alternatif iş modelleri ile sürdürülebilir olması bakımından yavaş gazetecilik diğer türlerden farklıdır. Yavaş gazeteciliğin önceliği kaliteli ve doğru haber kurgusunun oluşturulmasını sağlamaktır (Bulunmaz, Çetin, 2018: 126). Haberi hızlı bir şekilde yaymaya öncelik veren ve gazeteciliğin diğer toplumsal işlevlerini göz ardı eden günümüzdeki gazetecilik için düzeltici bir yapı olarak ortaya çıkan yavaş gazetecilik, dijital gazeteciliğin eleştirildiği hız konusuna bir alternatif olma konusunda umut vermektedir (Bilecen ve Bayraktutan: 2018, 348).

Yavaş Gazetecilik alanında ilk örnekler Amerika kıtası ve Avrupa' da görülmeye başlanmıştır. Yirmi birinci yüzyılın ilk çeyreği içinde bu girişimlerin sayısı onlarla ifade edilmektedir. 'Yavaş Hareketi', 'Yavaş Medya' gibi düşüncelerinin özünü taşıyan 'Yavaş Gazetecilik' girişimleri reklamdan daha çok abonelik ve kitlesel fonlama gibi finans modelleri ile çalışmaktadır. Dünya çapında son dönemde öne çıkan Yavaş gazetecilik girişimleri arasında Delayed Gratification, Long Play, Zetland, De Correspondent, Jot Down, Sprawl Calgary gibi kuruluşlar bulunmaktadır. Bu yayınların dışında The Atavist (Amerika Birleşik Devletleri), XXI (Fransa) Piqd.de CTXT (İspanya) Ricochet (Canada), Narratively (Amerika Birleşik Devletleri) gibi yavaş gazetecilik örnekleri de yer almaktadır.

\section{1. İtalya'da Yavaş Gazetecilik Girişimleri ve L'ora Del Pellice Örneği}

İtalya'da gazeteciliğin geçmişi Roma İmparatorluğu'nda Senato kararlarının halka sözlü ve yazılı olarak aktarıldığı 'Akta Pulica' ve daha sonraları 'Acta Diurna' gibi örneklere kadar giderken gerçek anlamda ilk gazetecilik emareleri 16. Yüzyılda Venedik'te görülmektedir. (Özçağlayan, 133) 17. ve 18. Yüzyıl boyunca dağınık ve irili ufaklı çok sayıda habercilik denemeleri olan İtalya'da gazetecilik anlamında ilk yayın 1859 yılında yayına başlayan La Nazione gazetesidir (Hibberd, 2008: 26). İtalya' da gazete endüstrisinin büyüme döneminin 19. yüzyılın sonuna doğru gerçekleştiği görülür. O dönemde günlük yayın yapan birkaç gazete 50.000'den fazla satar duruma gelirken İtalyan Birliği'nin sağlanması ile 1866 yılında kurulan Il Secolo, 1876'da kurulan Milano tabanlı Corriere della Sera gazetecilik alanının hâkimi durumuna gelmiştir. (Hibberd, 2008: 9) 20. Yüzyılın ilk yarısında Dünya savaşlarının gölgesinde geçerken gazeteler, ciddi ve edebi üslubuyla üst ve orta sınıftan okuyucuları kendine çekmeyi başarırlar. 20. Yüzyılda İtalya'daki ulusal gazetelerde bölgesel baskınlık 
dikkat çekicidir. Corriere della Sera, La Stampa, Il Mattino gibi birçok bölgesel ve çok bölgesel gazete yer almaktadır.

1990 sonrası medya alanında dijital gelişmelerin etkisi İtalyan medyası üzerinde de hissedilirken gazete okurunun günlük gazetelere erişirken interneti tercih etmesi sonucunu ortaya çıkarmıştır. Yazılı gazete tirajları hızla düşerken çevrimiçi gazete sayısı hızla artmıştır. Bu dönemde farklı dijital habercilik denemeleri yapılırken son 10 yıl içinde yavaş gazetecilik örnekleri de ülkede görülmeye başlamıştır. Çalışmamızın birinci bölümünde söz ettiğimiz gibi Yavaş Hareket, Carlo Petrini'nin çabaları ile İtalya'da gelişmiştir. Medya ve gazetecilik alanında da yavaşa olan eğilimin izlerine İtalya' da günümüzde rastlanmaktadır. Yirmi birinci yüzyılın başından itibaren, araştırmacı ve anlatıcı gazetecilik, geniş bir blog yelpazesinin doğuşuna paralel olarak ve yüksek kalitede gazeteciliğe dayanan basılı ve dijital yayınlara paralel olarak İtalya'da da artan bir okuryazarlık kazanmıştır. Ülke üzerinde çalışmalarımız sonucunda dikkate değer dört adet yavaş gazetecilik deneyimi tespit edilmiştir. Bunlar; Roma merkezli Yavaş Gazetecilik haber sitesi olan Il Salto, Yavaş Gazetecilik odaklı yerel İtalyan haber servisi L'Ora del Pellice, derinlemesine haber ve anlatı haberlerinin yer aldığ 1 Slow News web sitesi ve yazı ve röportajların yer aldığı Reportageitalia.it haber sitesidir.

2017' de kurulan Roma merkezli çevrimiçi web sitesi İl Salto'nun çalışanları çoğunlukla ulusal medya kuruluşlarından ayrılan gazetecilerden oluşmaktadır. Bağımsız medya oluşumu olan kuruluşun hedefi ekolojik yarar, sosyal sürdürülebilirlik ve paylaşılan refah temelli bir toplum oluşturma girişimlerini içeren öyküler ve deneyimlere odaklanmak olarak belirtilmektedir. Il Salto'nun tanıtım yazısında, "ekonomik ve finansal güç ile manipüle edilmiş ve kontrol edilen bilgiler arasında sıkışıp kalmış mevcut ve potansiyel okuyucuların problemini çözmek" hedefler arasında belirtilmiştir. Yayın kuruluşunun ekonomik yapısı diğer yavaş gazetecilik örnekleri gibi kitle fonlama biçimindedir.

2015 'te yayına başlayan, abonelik yapısı ile çalışan, ücret karşılığında bültenler hazırlayan Slow News ise dört İtalyan gazetecinin ortak çalışması olarak dikkat çekmektedir. Slow News bülteni, her gün medyada oluşturulan içerik akışından abone okurlar için seçilen yavaş ve derinlemesine haberlerden oluşmaktadır. Web sitesinde projenin felsefesi "çeşitli sorunların derinleştirme arzusuyla okuyuculara yöneltilmesi" biçiminde açılanmaktadır. 2009'da kurulan Reportageitalia ise Roma merkezli gazeteciler Angela Maura ve Emiliano Mancuso 'nun kurduğu bir yavaş gazetecilik projesidir. Proje ilk günden itibaren insan hikâyelerine yönelmektedir.

Çalışmamızın inceleme alanını oluşturan L'Ora del Pellice, İtalya'da başkenti Torino olan Piyemonte bölgesinde Pellice Vadisi olarak adlandırılan Pinerolo'yu ve yakın çevresini (Angrogna, Bagnolo Piemonte, Bibiana, Bricherasio, Bobbio Pellice, Campiglione Fenile, Cavour, Garzigliana, Luserna San Giovanni, Lusernetta, Osasco, Pinerolo, Prarostino, Rorà, Sanor) Torre Pellice ve Villar Pellice) kapsayan bir yayındır. Eylül 2016'dan beri yayımlanan dergi yerel olarak üç ayda bir okurla buluşmaktadır. 


\section{Yöntem}

Yapılan araştırmanın ana odağını "yavaş gazetecilik" kavramı ve ilk dönem yavaş gazetecilik pratikleri oluşturmaktadır. Çalışmada; Amerika, Kanada, Danimarka, İspanya, Hollanda ve İtalya'da ilk örneklerine rastlanan yavaş gazetecilik türüne örneklem olarak İtalya seçilmiştir. Özellikle medya alanının Türkiye ile tarihsel ve yöntemsel benzerlik taşıması nedeniyle çalışmada İtalya örneğine bakılmıştır. Çalışmamızın yöntemi olan nitel araştırmalar, örnek olayların ve bağlamların dilini kullanır. Nitel araştırmanın uygulama biçimi, farklı parçaların bir araya getirilmesi ve toplumsal süreçlerin örnek olaylar ile kendi sosyal bağlamında incelenmesidir. Nitel araştırmacılar, belirli ortamlardaki anlam yaratımlarına ve yorumlara bakarlar (Neumann, 2014: 30). Yapılan çalışma, konu merkezli bir yapıya sahiptir. Bu bağlamda, araştırmanın konusu olan "yavaş gazetecilik" ve "yavaş gazeteciliğin pratikleri" olgularına dair görüşme tekniğine başvurulmuştur. Çalışma sırasında döngüsel bir araştırma yolu izlenmiş ve çok sayıda gazetecinin görüşüne başvurulsa da ana konu ile ilgili olarak L'Ora del Pellice dergisinin editoryal ekibinin başında yer alan Michela Perrone ile görüşmeden elde edilen verilere yer verilmiştir. Derinlemesine görüşme yöntemi keşif odaklı ve açık uçludur. Bu yöntemin amacı görüşmecilerin açılımlarını ortaya koyarak; ortak tutum, düşünce veya fikirlere dayalı sonuçlar çıkarmaktır (Baş ve Akturan, 2008:111-116). Bu kapsamda aşağıdaki dört temel soru çerçevesinde görüş ve düşüncelerin öğrenilmesi hedeflenmiştir.

Araştırma Soruları:

- Yavaş gazetecilik, hızlı gazeteciliğe bir alternatif midir?

- Haber tüketicisinin derinlemesine araştırılmış, şeffaf, çok kaynaklı bir habercilik talebi var midır?

- Yavaş gazetecilik giderek güvenilmez duruma giden gazetecilik mesleğinin güvenini artıracak midır?

- Yavaş gazetecilik ekonomik bakımdan sürdürülebilir midir? 


\section{Bulgular ve Tartışma}

\section{Alternatif bir Platform Olarak Yavaş Gazetecilik}

21. yüzyılın başında gazeteciliğin internet tabanlı medya teknolojileriyle birleşmesi sonrası oluşan süreç, gazetecilik mesleği için büyük bir kaosun yaşandığı dönem olarak özetlenebilir. 'Çok fazla bilgi', 'bilgi yüklemesi', 'iletişimsel bolluk' gibi kelimelerle betimlenen yeni dönemde okur; daha gürültülü, daha telaşlı medya içerikleri ile karşı karşıya kalmıştır. Son çeyrek yüzyıl içinde hız odaklı gazetecilik karşısında 'Yavaş' fikri ile doğan bağımsız gazetecilik örnekleri yeni ve eleştirel bir alternatif medya alanını oluşturmaya başladılar. Yavaş düşüncesi başta olmak üzere meslek üzerinde değişim hedefleyen tüm çalışmaların amacı, gazetecilik mesleğinin hayatta kalması için hem bir fırsat hem de bir zorunluluk olarak görülmektedir (Brin, Charron ve Bonville: 2005).

Yavaş yaşamın savunucuları herkese yavaşlama fikrini empoze etme amacında değillerdir. Aksine, hız için bir alternatifin düşünülebilir ve mümkün olduğuna vurgu yapmaktadırlar (Parkins 2004, 367). İlk dönem yavaş gazetecilik deneyimlerinin hiçbiri kendilerini hızlı gazeteciliğin yerine ya da gazeteciliğin geleceği olarak düşünmemiştir. Bu ilk dönem küçük ölçekli, bağımsız habercilik oluşumları, ana akım gazetecilik organizasyonlarından özgürlükçü yapıları ve kâr anlayışına bakışları ile ayrılmaktadır. Yavaş gazetecilik, Mitchell Stephens'in yakın zamanda "bilgelik" gazeteciliği olarak adlandırdığ 1 şeyi vaat etmektedir: "Daha bilgili, daha açıklayıcı, daha etkileyici ya da mevcut olaylara ilişkin daha fazla empresyona dayanan, doyurucu anlatı tarzına sahip bir gazetecilik türü" (Stephens 2009: 4). Çalışma için görüştüğümüz L'Ora del Pellice Editörü Michela Perrone, Yavaş gazeteciliğin günümüz gazeteciliğinin bir alternatifi olduğunu düşünmediğini söylemektedir. L'Ora del Pellice'nin, başlangıcından itibaren en önemli amacı, bölgenin bir arşivini oluşturabilmek, okurlarına veri, bilgi ve röportajları tarihsel bağlamda sunmaya çalışmak olmuştur. L'Ora del Pellice'yi editoryal ekip, hem bir kitap hem de bir dergi olarak tanımlamaktadır. Dergide yer alan yazıların çoğu hazırlanması bakımından uzun zaman isteyen yazılardan oluşmaktadır.

Geleneksel basına baktığımızda uzun süreden beri özellikle dergicilik alanında haberin oluşturulma, okunma, yayma ve dolaşımda tutulma bakımından daha uzun zaman kullanılma eğilimi devam etmektedir (Hartley 2003, 252). Bu açıdan bakıldığında, yavaş gazetecilik yeni bir şey değildir (Le Masurier: 2015). Ayrıca, gazetecilik mesleği içerisinde de uzun süreden beri yavaş gazeteciliğin temel özellikleri arasında yer alan anlatı unsuru kullanılmaktadır. Gazeteciliğin ilk dönemlerinde anlatı gazeteciliği, habercilik alanında kullanılan bir yöntem olarak görülmüştür. Anlatı gazeteciliği; edebi gazetecilik, yeni gazetecilik veya uzun biçimli gazetecilik olarak da bilinir. Uzun biçimli haber yazıları gazetecilerin yaratıcı bir şekilde derinlemesine, kurmaca olmayan bir anlatı hazırlamasını gerektirir. Bu tür habercilik dergilerde sıkça görülür ve bir muhabirin bir konuyu farklı şekillerde ele almasına izin vermektedir (Deahl, 2018). Uzun biçimli yazı çok adımlı bir süreçtir. Gazeteciler, bir hikâye için çok sayıda insanla röportaj yapabilirler. Gazeteci, haberin 
olduğu yerdedir ve hikâyeye aşinadır. Sürükleyici bir hikâye anlatımı tarzı, okuyucuları geleneksel haber haberlerinden çok daha ayrıntılı bir hikâye içine çekmek için kullanılır. Günümüzde anlatı haberciliği çoğu ana akım medya organı tarafından yaygın olarak kullanılmamaktadır. L'Ora del Pellice Editörü Perrone, hem çevrimiçi haber merkezlerinin hem yazılı basın haber merkezlerinin ana odak noktasının hızlı habercilik olduğuna dikkat çekmektedir. Hızlı haber kültürünün egemenliğini sona erdirmek için edebi gazetecilik denemelerinin daha fazla olmasına ihtiyaç vardır. Ancak o zaman gerçek bir "yavaş gazetecilik" hareketi ortaya çıkabilir.

\section{Yavaş Gazetecilik Okuru}

Yirminci yüzyılın başında gazetecilerin mesleğini karakterize eden yapılar ve süreçlerin, gazete okur kitleleri arasındaki yeni alışkanlıklar ve talepler tarafından değiştirildiği görülmüştür. Yöndeşme odaklı bu yeni dönemde azalan gazete okurluğuna rağmen, haberlere olan talep ve anlık erişim daha da artmıştır (Siapera ve Veglis, 2012: 21-22). Çevrimiçi haber okuyucularının sayısı artarken basılı gazetelerin okur sayısı düşmeye başlamış hatta gençler arasında daha az yaygın duruma gelmiştir. Örneğin, 2000 yılında, 18 ila 34 yaşları arasındaki insanların yüzde 40'tan fazlasının günlük olarak gazete okumasına karşın, 35 ila 44 yaş arasındaki kişilerin yüzde 53'ünün ve 55 ila 64 yaş arasındaki kişilerin yüzde 66'sının gazete okuyucusu olduğu tespit edilmiştir (Boczkowski, 2004: 8). Son dönemde yapılan araştırmalarda ise 18-34 yaş arasındakilerin yüzde 37'sinin düzenli olarak herhangi bir haber ortamından bilgi aramayacağı ortaya çıkmıştır (Curran ve diğerleri 2013, 884). Böyle bir dönemde yavaş gazetecilik kuruluşları okur arayışına girmişlerdir. Yukarıda söz ettiğimiz gibi okur bulma konusunda büyük sorunlar yaşayan yayıncılar için yavaş gazeteciliğin yeni deney alanlarından biri olduğu görülmektedir. Drok ve Hermans (2016, 539-554) Hollanda özelinde yaptıkları çalışmada katılımcıların yaklaşık üçte birinin yavaş gazeteciliğe ilgi gösterdiğini ve önemli bir bölümünün gazete haberlerinin daha araştırmacı, kapsayıcı, işbirlikçi ve yapıcı olması gerektiğine dikkat çektiklerini ortaya koymuştur. Bilecen ve Bayraktutan da (2018: 349), yapılan çalışmaların yavaş gazetecilikle ilgilenen kayda değer bir okuyucunun varlığına işaret ettiğini söylerler. Aynı zamanda bu okuyucular multimedya anlatımlarına açık olan, etkileşimi destekleyen mobil teknolojileri kullanmaya alışık bir kitledir.

Dijital odaklı yeni dönemde, hem yayıncı hem de okur hızlı biçimde habere ulaşmayı beklemektedir. Yayıncı ve okur için tuzak bir durum olan bu hız sarmalı, bir haber sayfasından diğer bir haber sayfasına sürekli olarak geçen okurlardan oluşan bir yapıdır. Okur, bu ani tatmin ortamında gerçek hikâyeyi kaybetmeye başlamaktadır. Yavaş gazeteciliğin başladığ yer tam da burasıdır. Teknolojiye dayalı ve olabildiğince çabuk bilgi tüketme ihtiyacının oluştuğu bu dönemde daha yavaşa dair alternatifler çoğalmaktadır. İtalya'daki yavaş gazetecilik projesi Slow News'in başlangıç yazısında editoryal ekip şunları belirtmektedir: “...İnternet sonrası anlamsız içerik akışı ile birlikte, bilgiyi özümsemeye zaman bırakmayacak 
bir akışa boğulduk. (....) Gazeteciler olarak, gündemin sosyal medya ve tıklamalar tarafından belirlenmesinin sağlanmasından yorulduk. Okuyucular olarak, dikkatimizi dağıtmaktan yorulduk. Bu çalışmada bize hiçbir şey bırakmayan boş içeriklere tepki vermek istedik (https://www.slow-news.com)."

Yavaş gazetecilik ve türevleri, diğer internet sonrası habercilik örnekleri gibi okurun habere katılımcı ve kimi zaman üretici olarak dâhil olduğu bir kültürel dönemdir. Yeni ekosistemin temel özelliği ise kısmen blog örneklerinde görüldüğü gibi yeni aktörlere katılım ve ortak üretim zemini hazırlamasıdır (Atikkan ve Tunç, 2010: 133-214). Küresel anlamda yavaş gazetecilik projelerinin çoğunun başlangıcı ya da sürecinin devamlılığı okur ile etkileşim üzerine kuruludur. Editör Michela Perrone, L'Ora del Pellice'de bu etkileşim sürecini şu biçimde tanımlamaktadır. “.... Okurlarımız aynı zamanda destekçilerimizdir ve biz onlarla derinden temas halindeyiz. Periyodik olarak, önceki aylarda incelediğimiz konular hakkında tartışırız. (....) Başlangıçta onlar biraz şüpheliydi, ancak şimdi projemizin bir parçasılar. Şeffaflık istiyorlar ve kaynaklar hakkında sorular soruyorlar." L'Ora del Pellice örneği dışında Yavaş gazetecilik projelerinin çoğu okur odaklıdır. Örneğin Danimarka'daki bir yavaş gazetecilik projesi olan Zetland'ın Genel Yayın Yönetmeni Lea Korsgaard, okuyucuları ön plana çıkaran bir platform oluşturmak istediklerinin altını çizmektedir: “Okuyucularımızın pasif olmadıklarını düşünüyoruz. Onlar sadece okuyucu değil, aynı zamanda tepki göstermekten ve haberlerimizi dünyaya yaymaktan daha fazlasıdır, aynı zamanda bize yeni perspektifler kazandırma konusunda yeteneklidirler." (https://blog.wan-ifra.org)

\section{Dijital Çağda Gazeteciliğin Güven Sorunu ve Yavaş Gazetecilik}

Gazetecilik mesleğinin temel kuralları arasında bilginin elde edilmesi ve bu bilginin kontrol edilip doğrulandıktan sonra yayınlanması yer almaktadır. Bu temel parametre, gazeteciliği diğer alanlardan ayıran en önemli unsurdur (Yüksel, 2010: 163). Haber, kesinliği sağlanmış bilgiler üzerine kurulmalı, kesinleşmemiş bilgilere haberde yer verilmemelidir (Alemdar, Uzun: 95). Geleneksel gazetecilik döneminden itibaren kurallaşan "onaylanıp yayınlanan” haberlerin yerini hız ve teknoloji sarmalında "önce yayınlanıp ardından doğruluğu kontrol edilen" haberler almıştır. Bu kontrolsüz haber çağı sonrası etik anlamda sorunlar çoğalmıştır. Haberlerin hızlı akışı, gazetecilerin olaylar hakkında düşünmesini ve tutarlı bir anlatım inşa etmesini zorlaştırmaktadır. Bu durum da gazeteciliğin güvenilirliğini etkilemektedir. Bir yarış haline dönen gazetecilikte ilk olmak, mesleği aşırı basitleşme ve klişeleşme riski altında birakmaktadır (Bilecen, Bayraktutan, 2018: 346).

Yavaş gazetecilik, haber üretimindeki zamansallıktan çok daha fazlası olarak gazeteciliği ve kamuyu doğru bilgilendirmeye yönelik daha geniş bir yönelimi kapsamaktadır (Le Masurier, 2015, 141). Kısa haberler ve eksik bilgi içeren yeni habercilik ortamında yavaş gazetecilik, hikâyenin kalbindeki gerçeği ortaya koymaya çalışmaktadır. Dünya'da ilk yavaş gazetecilik denemelerinin çıkış noktasında da bu amaçlar yer almaktadır. İngiltere' de dünyanın ilk yavaş gazetecilik yayını gerçekleştiren haber yayını olan Delayed Gratification; kaliteli gazetecilik 
mottosuyla doğruluk, derinlik, bağlam, analiz ve uzman görüşü gibi değerlere odaklanmaktadır (https://www.slow-journalism.com/slow-journalism). Finlandiya'da yavaş gazetecilik yayını gerçekleştiren dijital bir yayın olan Long Play'de yayınlanan yazılar dergilerden daha uzun kitaplardan ise daha kısa olarak belirtilmektedir. Yolsuzluk, çocuk hakları, çevre, cinsiyetçilik gibi konuları ele alan Long Play, araştırmacı gazetecilik alanında uzmanlaşmıştır. Hollanda' da De Correspondent, yayına başlarken bir manifesto yayınlayarak okurlarıyla paylaşmıştır. Manifestonun ilk sırasında "günlük ama günün olaylarından fazlasını sunan, gazetecilik idealleriyle bezeli" olduklarını ve politik ideolojilerinin olmadıklarını belirtmişlerdir. Gazetenin önceliği kârlılıktan önce gazetecilik yapmak olarak vurgulanmıştır.

Çalışmamızın odak konusu olan L'Ora del Pellice'nin editoryal ekibi, yüzeysellik üzerine kurulu bilgi çağında, kendilerini derinlemesine bir gazetecilik projesine adadıklarını vurgular. Dergide her makalenin başında bazı simgelerden oluşan bir kimlik kartı bulunmaktadır. Bu simgelerin amacı, haber üzerinde kimin çalıştığını ve hangi rolde olduğunu okurun anlamasını sağlamaktır. Ayrıca, dergideki her yazıda karşı taraf figürünü işaret eden simge yer almaktadır. Burada, gazeteci tarafından bildirilen olgular, rakamlar ve bilgileri doğrulamaktan sorumlu çoğunlukla akademik denetmen bir kişinin yorumu bulunmaktadır.

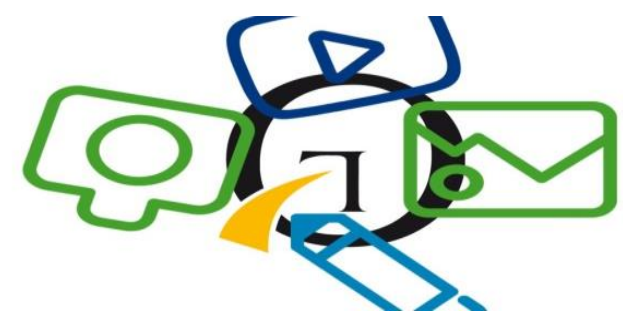

\section{Şekil 1: L'Ora del Pellice'de Sembol Örnekleri}

Editör Michela Perrone L'Ora del Pellice, yavaş gazetecilik türünün gazetecilik mesleğinin güven sorununun aşılması için yararlı olup olmayacağı sorusunu “Umarım” diye yanıtlıyor. Perrone'ye göre asıl cevap verilmesi gereken soru hızlı gazetecilikte haberlerin doğrulanmasıdır: “Haberleri doğrulatmak için yeterli zaman yok. Yeni dönemde amaç, habere ilk ulaşmaktır. Fakat bu şekilde çalışma biçimi gazeteciliğin güvenilirliğini yok etmektedir. (....) Yavaş gazetecilik vaktimizi alabilir, insanlarımızla konuşabilir, gözlerimizle görebileceğimiz bir yere götürebilir. Bütün bunlar işimiz için çok önemlidir."

Yeni dönemde tüketicilerin aktif üreticiler olarak bulunacakları daha yavaş bir yaklaşım, sorumlu bir vatandaşlık uygulaması olarak görülebilir. İtalya'da bir diğer yavaş gazetecilik örneği olan Il Salto'nun yayın politikası metninde şu sözlere yer verilmektedir: “(...) Ekonomik ve finansal güç tarafından manipüle edilmiş ve kontrol edilen bilgiler ile 'sahte 
haberler' ve popülizm arasında sıkışıp kalmış mevcut ve potansiyel okuyucularımızın problemini çözmeye yardımcı olmak istiyoruz.(...)"

Yavaş gazetecilik örnekleri mevcut güncelliğe bağlı olmasa bile, dünyayı anlamak için faydalı bilgiler sağlamanın önemli olduğuna inanmaktadır. Editör Michela, Perrone L'Ora del Pellice'de odaklandıkları en önemli konunun seçtikleri haberin sonucu olduğunu vurgulamaktadır. "Eğer bir temayı veya bakış açısını derinleştiremezsek, onu meşgul etmemeyi, duraklatmayı ve bizi tatmin edecek bir hizmet sunana kadar bilgi toplamayı sürdürmeyi tercih ederiz."

\section{Yavaş Gazeteciliğin Ekonomisi ve Sürdürülebilirlik}

Greenberg (2013), yavaş gazeteciliği tanımladığı çalışmasında hızlı haber kültürünün egemenliğinin sona ermesi gerektiğini savlarken üçlü kategoriden söz eder. İnternet tabanlı ucuz haber, geleneksel basın tarafından üretilen ortalama haber ve lüks haber. Greenberg'e göre yeni dönemde okur, gündelik rutin haberleri internet aracılığıyla ucuza hatta ücretsiz temin edebilmektedir. Geleneksel baskı gazeteciliği ile ortalama bir maliyetle hazırlanan ve yayınlanan habercilik ise ekonomik sorunlar yaşamakta ve her geçen gün kan kaybetmektedir. Yavaş Gazetecilik gibi makaleler, röportajlar ve diğer konular gibi derinlemesine bir haber pazarı ise yavaş yavaş gelişmektedir. İdeal bir haber ekosisteminde kaliteli ya da gerçek haber pahalıdır. Daha çok emek daha çok zaman ve masraf gerektiren bir çalışma biçiminin bir ekonomik düzeninin olması gerekir (Yüksel: 2010: 162).

Yavaş anlayışında sürdürülebilirlik sorunu, ilk dönemde, yerel çiftçileri desteklemek için toplum destekli tarım gibi modeller geliştiren yavaş gıda hareketine kadar indirgenebilir. Çoğunlukla bir çiftliğin yakınındaki kentsel bir bölgede yaşayanlar, mevsimin başında hisse satın alarak çiftçinin hasat zamanında haftalık veya iki haftada bir ürün teslimatı karşılı̆̆ında gerekli tohum ve ekipmanları elde etmelerini sağlamışlardır. Buna benzer yapılanmalar 'Yavaş Medya' ve ' Yavaş Gazetecilik' içinde ilk denemelerde görülmüştür. Çoğu yavaş gazetecilik deneyimi, tüketici destekli gazetecilikle ilgili deneyler gerçekleştirmiştir. Çok az da olsa bu konuda başarılı olmuş yayıncı çıkmıştır. Yerel ve organik gıdalarda olduğu gibi, yavaş gazeteciliğin başarısı için de okurların büyük bir kısmının ödeme yapmaya istekli tüketici grubunda olması gerekmektedir.

"Yavaş" gazeteciliğin derin raporlama ve hikâye anlatımının katma değerinin, titiz üretim süreciyle orantılı bir fiyat olması gerekir. Medya kuruluşlarına ücretsiz içerik sağlamaya teşvik eden reklam verenlerin giderek daha fazla baskın hale getirdiği bir haber ekosisteminde, yavaş gazetecilik yayıncılarının çoğu, okuyucuların yüksek gazetecilik standardına göre yazılmış haberler için ödeme yapmaya istekli olacağına inanmaktadır (Dowling, 2016). Reklam vereni olmayan ve okurların finanse ettiği geniş bütçeli ilk yayın olma özelliği taşıyan De Correspondent'in izlediği başarı grafiği dünyadaki birçok yayıncı için ilham kaynağı olabilir. 2013'den beri Hollanda'da yavaş gazetecilik yayını gerçekleştiren De Correspondent'un tüm fonlamasını okuyucular yapar. Sitede reklam alanları bulunmamaktadır. 
İlk dönem yavaş gazetecilik denemelerinde çok farklı gelir modellerine rastlanmaktadır. Basılı ve dijital yavaş gazetecilik yayıncılarının çoğu, okuyucunun dikkatini çekmek için editoryal içerikle rekabet eden görüntülü reklam, afiş ve pop-up reklamlarını ya ortadan kaldırmış ya da çok kısıtlamışlardır (Dowling, 2016: 531). Bu uygulamaların yerine, çok çeşitli gelir paketleri ortaya çıkmıştır. Örneğin İspanya'da Yavaş Gazetecilik dergisi Jot Down, ana ürünlerindeki alanın yüzde 10'unu sponsorlara satarak baskı aboneliği kârını artırmaktadır (Breiner 2015). Yavaş gazeteciliği sürdürülebilir hale getirme konusunda başarılı olmuş yayınlardan birisi 10.000 ila 20.000 kelimelik uzun biçimli anlatı makaleleri yayınlayan Atavist Dergisi'dir. 2011 yılında yayına başlayan site ilk günden itibaren 4 milyon dolardan fazla yatırımcı desteği alırken, bireysel abonelerin kendi içeriğini yayınlamak için kullandıkları ve şirketin bir bütün olarak gelirini arttıran dergiden ayrı bir yayın platformu oluşturulmuştur (niemanreports.org). Delayed Gratification, tamamen abonelik sistemi ile ekonomik olarak sürdürülebilirliğini sağlarken bir başka örnek Long Play, kısa makaleler için ücret istemezken uzun biçimli yüksek kaliteli gazetecilik ürünlerini ücretli olarak okurlarına sunmaktadır. Danimarka'da yavaş gazetecilik yayını gerçekleştiren Zetland.dk, ekonomik anlamda abone temelli çalışmaktadır. Yukarıdaki örneklerde gösterdiği gibi yavaş gazetecilik odaklı medya pazarında başarılı olmak için kaliteli gazetecilik için para ödemeye istekli bir okur topluluğu oluşturmak büyük önem taşımaktadır.

İnceleme çalışmamız olan L'Ora del Pellice, ekonomi ve sürdürülebilirlik bakımından dergi üye katkıları, gazete bayii satışı ve tanıtım alanındaki çalışmalarla gelir elde etmektedir. L'Ora del Pellice'nin iş modeli hedefi bir yayıncının gücüne değil, okuyucunun desteğine dayanan bir iş modelidir. L'Ora del Pellice'nin Editörü Michela Perrone okur ilişkilerini ve ekonomik durumu şu biçimde özetlemektedir: “L'Ora del Pellice bölgenin sesidir. Bölge halkı, arkasında gücü olmayan bir gazetecilik projesini desteklemektedir.(...) Dergi; mart, haziran, eylül ve aralık olmak üzere yılda dört sayı yayınlanmaktadır. Projemizin gücü her üç ayda bir, okuyucularımızın bize satın alarak güvenlerini vermeye karar verdiklerinde ve şirketler kendilerini tanıtmaya karar verdiklerinde görülmektedir."

L'Ora del Pellice' de diğer birçok yavaş gazetecilik projesinde olduğu gibi geleneksel reklamlar yer almamaktadır. Bunun yerine, bölgedeki şirket ve işletmelerin hikâyelerine Carosello (atlı karınca) adlı bir bölümde yer verilmektedir. Bu bölümde normal bir reklam metninin ötesinde slogan tarzı olmayan tanıtım içerikleri yer almaktadır. Burada reklam verenin kendisine, çalışma şeklini ve özelliklerini ayrıntılı bir biçimde anlatmasına izin verilir. (http://loradelpellice.it/carosello/). L'Ora del Pellice'nin web sitesinde yer alan iki adet reklam örneğinde ürün üreten kuruluşun tüm imalat sürecini anlatan video ve bir şehir okulunun bilgileri ayrıntılı bir biçimde verildiği görülmüştür (http://loradelpellice.it/il-liceo-valdese-lastoria-e-il-futuro). 

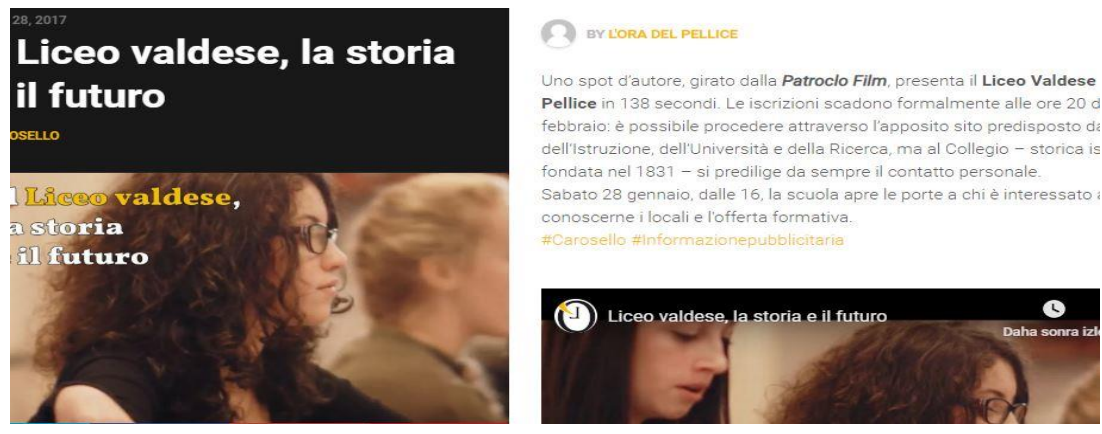

Şekil 2: Lora del Pelice Web Sitesi Reklam Örneği

İnceleme çalışmamız olan L'Ora del Pellice'nin Editörü Michela Perrone, yavaş gazeteciliğin sürdürülebilirliği üzerine sorumuza "Sürdürülebilir olarak düşünüyorum ama henüz kanıtlayamıyorum" diye yanıt veriyor: "İki yıldır varız ve şu anda projemiz sürdürülebilir. Kültürel dernek olarak dergimizi yayınlıyoruz, ancak bölgemizdeki diğer kültürel projelere de katılıyoruz. Bu şekilde herkese ödeme yapacak kaynaklara sahip olabiliriz. Bu bizim için çok değerli bir proje, ama şimdilik sadece bu kaynaklarla yaşayamayız..(...) Bu yüzden insanları bize güvenmeye ve dergimizi almaya ikna etmeliyiz." Perrone, güncel mevcut gazetecilik alanının bile sürdürülebilir olup olmadığının soru işareti olduğunu belirtiyor.

\section{Sonuç}

Yavaş gazetecilik, hız sarmalında süreklilik arz eden baskın geleneksel gazetecilik eğilimine bir tepki olarak ortaya çıkan ve titiz, yaratıcı, üretken ve tüketmek için gerekli zamanı yeniden düşünmeye davet eden bir tür olarak görülmektedir. İtalya özelinde ilk dönem yavaş gazetecilik uygulamalarının incelendiği bu çalışmada yavaş gazeteciliğin geleneksel medyaya olan alternatifliği, yavaş habercilik tüketicisi, mesleğin güvenirliği ve ekonomik bakımdan sürdürülebilirliği tartışılmıştır. İlk dönem yavaş gazetecilik deneyimleri kendilerini hızlı gazeteciliğin yerine ya da gazeteciliğin geleceği olarak düşünmemektedir. Bu ilk dönem küçük ölçekli, bağımsız habercilik oluşumları, ana akım gazetecilik organizasyonlarından özgürlükçü yapıları ve kâr anlayışına bakışları ile ayrılmaktadır. Yavaş gazetecilik deneyimleri hızlı haber kültürünün egemenliğini sona erdirmek için edebi gazetecilik denemelerinin daha fazla olmasına ihtiyaç olduğunu göstermiştir. Yavaş gazetecilik ve türevleri diğer internet sonrası habercilik örnekleri gibi okurun, habere katılımcı ve kimi zaman üretici olarak dâhil olduğu bir kültürel dönemdir. L'Ora del Pellice örneği dışında da çoğu Yavaş gazetecilik projesi okur odaklıdır. Hızlı habercilik odaklı çalışma biçimi gazeteciliğin güvenilirliğini yok ederken yavaş gazetecilik örnekleri doğru habercilik için haber alanında azınlıkta projeler olarak tanımlanabilir. Yavaş Gazetecilik yayıncılarının çoğu okuyucularının gönüllü bağışları ile ekonomik olarak yaşayan kitle kaynak modeli ile hareket eden yapılardır. İnceleme çalışmamız olan L'Ora del Pellice'de ekonomi ve sürdürülebilirlik bakımından dergi üye katkıları ve geleneksel medya tarzı yöntemleri ile gelir elde etse de uzun vadeli olarak ekonomik anlamda endişeler taşınmaktadır. 


\section{Kaynakça}

ALBALAD J.M. (2015): Slow journalism para una nueva audiencia digital. El caso de Longform.org (2010-2015), Revista de Comunicación 14, 7-25.

ALEMDAR K. ve UZUN R (2013). Herkes İçin Gazetecilik, Ankara, Tanyeri Kitap.

ATIKKAN Z. TUNÇ A. , (2010) Blogdan Al Haberi: Haber Blogları, Demokrasi, Gazeteciliğin Geleceği Üzerine, İstanbul, Yapı Kredi Yayınları.

BALL, B (2016): Multimedia, Slow Journalism as Process, and The Possibility of Proper Time, Digital Journalism v.4 n.4, 432-444.

BAŞ T. ve AKTURAN,U., (2008) Nitel Araştırma Yöntemleri, Seçkin Yayıncılık.

BARRANQUERO A. y JAURRIETA, G. (2016): Slow Journalism in Spain. New magazine startups and the paradigmatic case of Jot Down, Journalism Practice v.10 n. 4, 521-538

BELT, D. (2015): Slow Journalism and the Out of Eden Walk Pages, Digital Journalism v. 4, n. 4, 547-562.

BİLECEN N.S.,BAYRAKTUTAN G.(2018) İnternet Çağında Gazetecilik İçin Tartışmalı Bir Kavram: 'Yavaşlık, Akdeniz Üniversitesi İletişim Fakültesi Dergisi, Kasım 2018 Özel Sayı,341-354.

BOCZKOWSKİ, P. (2004). The processes of adopting multimedia and interactivity in three online newsrooms. Journal of Communication, 54, 197-213.

BRIN, C, Charron J, ve BONVILLE J.. (2005). Nature et transformations du journalisme : théorie et recherches empiriques. Quebec: Presses de l'Université Laval.

BULUNMAZ B., ÇETIN B., (2018) Yavaş Gazetecilik Geçmiş mi Gelecek mi?, İstanbul, Türkmen Kitabevi.

CHUNG, D. S. y YOO, C.-Y. (2008): Audience motivations for using interactive features: Distinguishing use of different types of interactivity on an online newspaper, Mass communication \& Society, $v$. 11, n. 4, 375-397.

COOPER, C. (2009). The Death of Slow Journalism, American Journalism Review, (Çevrimiçi): http://ajrarchive.org/article_printable.asp?id=4789.

CORYDON, S. (2015), Slow journalism - an oxymoron? A discussion of the potential for slow journalism in Denmark, Haugaard Frederiksberg. Master Thesis, Copenhagen Business School.

DAVIES, N. (2008). Flat Earth News, London, Vintage Books.

DEAHL, R. (2018), What Is Narrative Journalism? (Çevrimiçi): https://www.thebalance.com/what-isnarrative-journalism-2316035

DEĞİRMENCİĞLU G., Dijitalleşme Çağında Gazeteciliğin Geleceği ve İnovasyon Haberciliği, TRT Akademi Dergisi, Cilt 01 Sayı 02 Temmuz 2016 Dijital Medya Sayısı, 591-606.

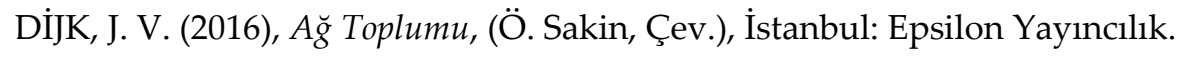


DOWLING, D. (2015): The Business of Slow Journalism. Deep storytelling's alternative economies, Digital Journalism, v. 4, n. 4, 530-546.

DROK, N. y Hermans, L. (2016): Is there a future for slow journalism? The perspective of younger users, Journalism Practice v.10, n.4, 539-554

GESS, H. (2012): Climate change and the possibility of 'slow journalism, Ecquid novi: African journalism studies, v. 33, n. 1, 54-65.

GORBACHEV A., (2016) Business models of digital longform publications, Çevrimiçi: https://mospace.umsystem.edu/xmlui/bitstream/handle/10355/56060/research.pdf?sequence=2 \&isAllowed $=\mathrm{y}$

GREENBERG, S. (2007): Slow Journalism, Prospect Magazine, www.prospectmagazine.co.uk/magazine/slowjournalism/\#. U06gsFV_uSo

GREENBERG, S. (2013) Slow Journalism in the Digital Fast Lane, In Global Literary Journalism: Exploring the Journalistic Imagination, Ed: Richard Lance Keeble ve John Tulloch, 381-393. New York: Peter Lang.

GÜVEN, E., (2011) Yavaş Güzeldir: “Yavaş Yemekten "Yavaş Medyaya Hızlı Tüketime Dair Bir Çözüm Önerisi, Selçuk Iletetisim Dergisi, Cilt 7, Sayı 1. 113-121.

HARCUP, T. (2014). A Dictionary of Journalism. Oxford: Oxford University Press.

HiBBERD, M. (2008), Media in Italy: Press, Cinema and Broadcasting from Unification to Digital, Buckingham, Open University Press.

HONERO, C. (2008), Yavaş: Hız Çılgınlığına Başkaldıran Yavaşlık Hareketi, Çev: Esen Gür, İstanbul: Alfa Yayınları.

KUNDERA, M. (2018) Yavaşlık, Çev: Özdemir İnce,18. Baskı, Can Yayınları, İstanbul.

LASSILA-MERISALO, M. (2014): Story First. Publishing Narrative Long-Form Journalism in Digital Environments, Journal of Magazine \& New Media Research v. 15, n. 2, 1-16.

LE MASURIER, M. (2015): What is slow journalism, Journalism Practice, v. 9, n. 2, 138-152.

NEVEU, E. (2016): On not going too fast with slow journalism", Journalism Practice v. 10. n.4, 448-460

MENGÜ, M. (2018). Churnalism - Hazırcı Gazetecilik, İnternet Haberciliği: Kuram, uygulama ve eleştiri, Ed: Kenan Duman, İstanbul, Beta Yayınları.

NEUMANN L. (2014), Toplumsal Araştırma Yöntemleri, Ankara, Yayın odası Yayınları.

ÖZÇAĞLAYAN, M. (2008) Gazetelerin Gelişimi ve Gazeteciliğin Geleceği (Yeni Teknolojiler ve Medya Ekonomisi Açısından Genel Bir Değerlendirme), İletişim Dergisi, 131-160.

PARKINS W., Out of Time: Fast Subjects and Slow Living, Time and Society, 13, 2.3.363-382.

PEDRIZA, S.B. El Slow Journalism en la era de la infoxicación, Doxa Comunicación, Volume 25, Number 1, 2017, ss. 129-148(20) 
PETRIE, N. (2015): "The year news slow down", Blog NiemanLab http://www.niemanlab.org/2015/12/the-year-news-slowsdown/ Erişim Tarihi02/01/2019.

PETRINII, Carlo. 2001. Slow Food: Collected Thoughts on Taste, Tradition, and the Honest Pleasures of Food. White River Jct., VT: Chelsea Green.

PETRINİ C., PADOVANİ G., (2012) Slow Food Devrimi (Çevirmen: Çağrı Ekiz, İstanbul: Sinek Sekiz Yayınevi.

RİTZER G, (2011) Büyüsü Bozulmuş Dünyayı Büyülemek, Çev: Şen Süer Kaya, 2. Baskı, İstanbul, Ayrıntı Yayınları.

SİAPERA. E. ve VEGLİS. A. (2012). The Handbook of Global Online Journalism, UK:Wiley-Blackwell press

STEPHENS, M. (2009). Beyond News: The Case for Wisdom Journalism. Discussion Paper Series, Joan Shorenstein Center on the Press, Politics and Public Policy, Harvard University, John F. Kennedy School of Government. 1-28.

STEVEN R., (2014) Basılı dergilerin geleceği, Creative Review, Kasım 2014 Çeviri: Leyla Tonguç Basmacı, Çevrimiçi: http://gmk.org.tr/uploads/news/file-1470739146354807845.pdf

YÜKSEL, E., (2010) Medya ve Habercilik, Konya, Çizgi Kitabevi. 